\title{
Efek Bekam terhadap Penurunan Nyeri Dismenore pada Mahasiswa
}

\author{
Effects of Cupping on Dismenore Pain Reduction \\ to Students
}

\author{
Yusro Hadi Maksum ${ }^{1, \varpi}$, Sri Lestariningsih ${ }^{1}$, Septi Widiyanti $^{1}$ \\ ${ }^{1}$ Jurusan Kebidanan, Politeknik Kesehatan Tanjung Karang, Indonesia \\ ${ }^{凶}$ Corresponding author: yusrohadi@ poltekkes-tjk.ac.id
}

\section{Kata kunci: \\ Disminore, \\ Nyeri, \\ Bekam.}

Keyword:

Dysmenorrhoea,

Pain,

Cupping.

\begin{abstract}
Abstrak
Latar Belakang: Prevalensi wanita Indonesia yang mengalami disminore diperkirakan 55\% wanita usia produktif tersiksa oleh nyeri selama menstruasi. Disminore yang paling umum dilaporkan terjadi pada 60\%-90\% remaja. Tujuan penelitian: Untuk mengetahui efektifitas bekam terhadap penurunan nyeri dismenore pada mahasiswi. tahun 2018. Metode: Penelitian ini menggunakan rancangan pra eksperimen dengan one group pretest and posttest design yang dilakukan tahun 2018. Populasi penelitian adalah mahasiswi yang mengalami nyeri berat atau skala nyeri 7-9 (skala 0-10) dengan jumlah sampel minimal 32 orang. Teknik sampling menggunakan consecutive sampling. Variabel yang dianalisis adalah pengukuran skala nyeri disminore responden sebelum dan sesudah perlakukan bekam. Analisis data secara analisis univariat dan analisis bivariate menggunakan paired samples T-test. Hasil: Ada perbedaan skala nyeri dismenore antara sebelum $(6,78)$ dan sesudah tindakan bekam $(5,09)$. Selisih nyeri 1,69 dengan p value 0,000. Simpulan: Bekam memberikan efek atau pengaruh menurunkan skala nyeri pada dismenore bekam dapat menjadi salah satu terapi atau upaya yang direkomendasikan untuk mengatasi gangguan rasa nyeri disminore dan bebas dari efek samping mengkonsumsi obat-obat kimiawi.
\end{abstract}

\begin{abstract}
s
Background: The prevalence of Indonesian women with dysmenorrhoea is estimated at 55\% of women of childbearing age suffering from pain during menstruation. The most common dysmenorrhoea is reported in $60 \%-90 \%$ of adolescents. Purpose: To determine the effect of cupping on dysmenorrhea pain in students 2018. Methods: This study used a pre-experimental design with one group pretest and posttest design conducted in 2018. The study population was a student who experience severe pain or pain scale 7-9 (scale 0-10) with a minimum sample size of 32 people. The sampling technique uses consecutive sampling. The variable analyzed was the measurement of the respondent's disminore pain scale before and after cupping treatment. Data analysis by univariate analysis and bivariate analysis using paired samples T-test. Results: There was a difference in dismenore pain scale between before (6.78) and after cupping (5.09). Difference in pain 1.69 with p value 0,000. Conclusion: Cupping provides the effect or effect of reducing the pain scale on dysmenorrhea. Cupping can be one of the therapies or efforts that are recommended to deal with dysmenorrhoea pain disorders and free from the side effects of consuming chemical drugs.
\end{abstract}

Copyright $(2019$ Jurnal Kesehatan Metro Sai Wawai. All rights reserved. 


\section{Pendahuluan}

Nyeri haid atau dismenore merupakan gangguan fisik yang sangat menonjol pada wanita yang sedang mengalami menstruasi berupa gangguan nyeri/kram pada perut (Lestari, 2011). Beberapa wanita merasakan keluhan berupa nyeri atau kram di daerah perut bagian bawah saat haid berlangsung maupun sebelum, bahkan ada yang sampai pingsan karena tidak dapat menahan rasa sakitnya. Gangguan seperti ini bila rasa sakit tidak disertai dengan riwayat infeksi maka disebut disminore primer. Dan bila rasa sakit disertai dengan infeksi atau peradangan maka disebut disminore sekunder (Prabekti, 2012).

Disminore yang paling umum dilaporkan terjadi pada 60\% - 90\% remaja, dan merupakan penyebab paling sering alasan ketidakhadiran di sekolah dan pengurangan aktivitas sehari-hari (Pediatri, 2010 dikutip oleh Savitri, 2015). Data WHO tahun 2012 menjelaskan dari sebesar 1.769.425 jiwa (90\%) wanita yang mengalami disminore berjumlah 10 - 15\% mengalami disminore berat. Penelitian di China pada tahun 2010 menunjukkan sekitar 41,9\% sampai 79,4\% remaja mengalami disminore primer, dimana 31,5\% sampai dengan 41,9\% terjadi pada usia 9-13 tahun, dan 57,1\% sampai dengan 79,4\% terjadi pada usia 14-18 tahun. Sebanyak 50\% wanita mengalami disminore tanpa patologi pelvis, 10\% mengalami nyeri yang hebat hingga tidak mampu beraktivitas 1 sampai 3 hari di setiap bulannya, dan 25\% mengalami ketidakhadiran di sekolah (Reder, dkk., 2011 dalam (Yurisda, 2015).

Di Malaysia prevalensi disminore pada remaja sebanyak 62,3\% (Ningsih, 2011). Di Indonesia angka kejadian disminore terdiri dari disminore primer 54,89\% dan disminore sekunder 9,36\% yang menyebabkan mereka tidak mampu melakukan kegiatan apapun, sehingga dapat berdampak menurunkan kualitas hidup pada individu masing-masing (Andarini, 2012). Sedangkan, Proverawati (2009) mengungkapkan bahwa prevalensi wanita Indonesia yang mengalami disminore diperkirakan 55\% wanita usia produktif tersiksa oleh nyeri selama menstruasi (Proverawati, 2009). Hasil penelitian oleh Arnis tahun 2012 angka kejadian disminore di Jawa Barat cukup tinggi. Sejumah kejadian dismenore sebanyak 54,9\% wanita mengalami disminore, terdiri dari 24,5\% mengalami disminore ringan, 21,28\% mengalami disminore sedang dan 9,36\% mengalami disminore berat (Savitri, 2015).

Penyebab dari disminore primer terdiri dari beberapa faktor, yang pertama yaitu faktor kejiwaan, faktor konstitusi, faktor endokrin atau hormone (Laila, 2011). Sedangkan, penyebab disminore sekunder diketahui karena ada masalah di organ reproduksi, seperti endometriosis, tumor pada rahim, atau adanya peradangan kronik pada panggul bagian dalam, alat kontrasepsi IUD juga dapat mempengaruhi munculnya disminore pada sebagian orang, nyeri sekunder muncul pada usia 20-30 tahun (Sari, 2012).

Nyeri menstruasi yang dialami wanita dapat berakibat pada kehidupan mereka sehari-hari. Diperkirakan wanita Amerika kehilangan 1,7 juta hari kerja setiap bulan akibat disminore (Bobak, 2012). Remaja yang mengalami disminore mempunyai lebih banyak hari libur kerja dan prestasinya kurang begitu baik disekolah dibandingkan remaja yang tidak terkena disminore (Hacker \& Moore, 2015). Pada beberapa kasus tidak sedikit perempuan yang mengalami nyeri haid yang berkepanjangan dan terus-menerus merasakan sakit, bahkan tidak bisa beraktivitas apapun selama haid karena nyeri yang tidak tertahankan (Anurogo \& Wulandari, 2012).

Penanganan nyeri haid bisa dilakukan secara farmakologi dan non farmakologi, beberapa terapi non farmakologi, diantaranya akupuntur, bekam, relaksasi napas dalam dan herbal. Banyak hal lain yang dapat dilakukan wanita untuk mengurangi rasa nyeri pada disminore primer, misalnya penggunaan kompres hangat/ mandi air hangat, mengkonsumsi obat-obatan analgetik, olahraga teratur, akupunktur ataupun akupresure, bekam dan mengkonsumsi produk-produk herbal, memperbanyak minum air putih, menggunakan aroma terapi, melakukan relaksasi, minum teh hangat dan masih banyak lagi (Laila, 2011).

Metode pengobatan bekam sekarang sudah mulai memasyarakat. Metode pengobatan bekam merupakan pengobatan yang disunahkan Nabi Muhammad Shalallahu 'alahi wasalam kepada seluruh 
umat Islam, begitu pentingnya sangat pentingnya bekam, Allah Suhanaa wa ta'aala memberikan perintah berbekam bersamaan dengan perintah shalat, artinya bekam punya arti yang sangat penting dalam kehidupan manusia sebagaimana pentingnya shalat. Bekam dapat menyembuhkan berbagai macam penyakit, sebagai contoh penyakit pada organ dalam seperti maag dan asma, penyakit organ reproduksi wanita seperti amenorea dan disminore, gangguan sistem penginderaan seperti sinusitis, serta nyeri pada otot, tulang, dan sendi (Lestari, 2011)

Berdasarkan survei awal yang dilakukan pada bulan September 2018, dari 453 orang mahasiswi yang mengalami disminore setiap bulan berjumlah 272 (60\%), terdapat 35 orang (12,92\%) dengan nyeri berat yang mengganggu aktifitas belajar. Berbagai upaya untuk mengatasi masalah disminore tersebut dengan mengkonsumsi obat pereda nyeri $(23,5)$, mengkonsumsi minuman tradisional $(23,5 \%)$ dan sebagian menahan atau mengadapatasi tanpa tindakan di atas (52,9\%). Alasan mahasiswi tidak mengkonsumsi obat-obatan, disebabkan tidak ingin mengalami ketergantungan. Upaya mengatasi nyeri pada disminore salah satunya adalah dengan menggunakan cara-cara titik bekam, yang dicontohkan Rosululloh Shalallahu 'alahi wasalam. Penelitian bertujuan mengetahui efektifitas bekam terhadap penurunan nyeri dismenore

\section{Metode}

Rancangan penelitian yang digunakan adalah pre eksperimen dengan one group pretest and posttest design, tidak memiliki kelompok pembanding (kontrol), tetapi paling tidak sudah dilakukan observasi pertama (pretest) yang memungkinkan menguji perubahan-perubahan yang terjadi setelah adanya perlakuan bekam setelah itu dilakukan observasi kedua (nyeri sesudah) yang dilaksanakan pada

Populasi penelitian adalah mahasiswi yang mengalami nyeri berat atau skala nyeri 7-9 (skala 010) dengan jumlah sampel minimal 32 orang. Teknik sampling menggunakan consecutive sampling dengan pembatasan melalui pemilihan yang kriteria inklusi dan eksklusi. Kriteria inklusi pada sampel penelitian ini adalah: (1) responden mengalami disminore dengan skala berata (7-9), mempunyai riwayat disminore dalam 3 bulan terakhir; dan (2) bersedia dan tidak mengkonsumsi obat-obat analgetika atau terapi apapun selama dalam proses penelitian. Sedangkan, kriteria eksklusi pada sampel penelitian ini adalah: (1) tingkat nyeri sangat berat; (2) mengalami nyeri disertai dengan kelainan ginekologi (disminore sekunder); dan (3) minum obat atau terapi lain pereda nyeri.

Pengumpulan data dengan menggunakan instrumen penelitian kuesioner. Kuesioner mengeksplorasi data karakteristik dan pengukuran intensitas nyeri dari responden penelitian. Informasi data karakteritik yang diperoleh meliputi: biodata, menarche, siklus menstruasi, penatalaksanaan ketika disminore. Sedangkan, pengukuran intensitas nyeri menggunakan skala penilaian numeric rating scale (dalam hal ini klien menilai nyeri dengan mengunakan skala 0-10) dan the face pain scale (menggunakan skala 0-5). Untuk meminimalkan bias pengumpulan data menggunakan data primer dan sekunder. Data primer dengan mengobservasi responden sebelum dan setelah perlakuan bekam formurlir observasi check list untuk mengukur nyeri.

Perlakuan dengan intervensi bekam pada titik bekam ( $S a q)$ pada lokasi bagian tubuh yang akan dilakukan bekam, yaitu pada tungkai bawah antara lutut dan pergelangan kaki bagian dalam kira-kira 4 jari diatas mata kaki bagian dalam. Bekam dilakukan antara hari ke-7, 6, 5, 4, 3 atau hari ke-2 sebelum mengalami disminore. Intervensi diberikan pagi atau sore selama 60 menit. Data yang telah diperoleh dilakukan analisis data menggunakan analisis univariat dan bivariat. Analisis bivariat menggunakan paired samples T-test.

\section{Hasil}

\section{Skala nyeri Dismenorae pada Responden Sebelum dilakukan perlakuan Bekam}

Skala nyeri responden sebelum dilakukan bekam ini diambil pada responden yang mengalami skala nyeri dengan skala sedang sampai berat ( $\geq$ skala 4 ). Responden diberi perlakuan bekam pada hari 
minimal sebelum 7 hari sampai 2 hari menjelang menstruasi. Tabel 1 memperlihatkan sebagian besar $(56,25 \%)$ mengalami nyeri disminore berat. Setelah dilakukan perlakuan bekam terlihat pada tabel 2 tingkat nyeri yang dialami sebagian besar $(84,375 \%)$ mengalami nyeri disminore sedang dan yang menurun menjadi nyeri tingkat ringan terdapat $6,25 \%$ (Skala nyeri $0-10$ ).

Tabel 1.

Distribusi nyeri disminore berdasarkan tingkat skala nyeri

\begin{tabular}{ccccc}
\hline \multirow{2}{*}{ Skala Nyeri } & \multicolumn{2}{c}{ Sebelum Perlakuan } & \multicolumn{2}{c}{ Sestelah Perlakuan } \\
\cline { 2 - 5 } & Frekuensi & Persentase (\%) & Frekuensi & Persentase (\%) \\
\hline Nyeri Ringan (1-3) & 0 & 0 & 2 & 6,25 \\
Nyeri Sedang (4-6) & 14 & 43,75 & 27 & 84,375 \\
Nyeri Berat (7-10) & 18 & 56,25 & 3 & 9,375 \\
Jumlah & 32 & 100 & 32 & 100 \\
\hline
\end{tabular}

\section{Analisis Bivariat}

Analisis bivariat untuk mengetahui pengaruh perlakuan bekam terhadap tingkat nyeri disminore menggunakan uji t independen dengan tingkat kepercayaan $95 \%$ dan $\alpha 5 \%$ atau 0,05 . Hasil analisis pada tabel 2 memperlihatkan hasil rata-rata nilai nyeri disminorea sebelum dilakukan tindakan perlakuan bekam dengan skala nyeri 6,78 (SD 0,98) atau nyeri sedang. Sedangkan, sesudah responden mendapatkan perlakukan bekam memperlihatkan rata-rata skala nyeri disminorea 5,09 (SD 1,05). Tabel 3 memperlihatkan perbedaan rata-rata skala nyeri sebelum dan sesudah bekam dengan penurunan skala nyeri 1,69 (SD 0,93). Selanjutnya, dilakukan uji statistik menunjukkan ada perbedaan yang signifikan skala nyeri disminorea sebelum dan sesudah diberikan perlakuan bekam $(\mathrm{p}=0,000)$.

Tabel 2.

Rata-Rata Penurunan Skala Nyeri Disminorea Sebelum dan Sesudah Perlakuan Bekam

\begin{tabular}{lcccc}
\hline \multicolumn{1}{c}{ Skala Nyeri Disminore } & Mean & n & SD & SE \\
\hline Sebelum bekam & 6,78 & 32 & 0,98 & 0,17 \\
Sesudah bekam & 5.09 & 32 & 1,06 & 0,19 \\
\hline
\end{tabular}

Tabel 3.

Hasil Analisis Bivariat Sebelum dan Sesudah Perlakuan Bekam

\begin{tabular}{ccccccccc}
\hline \multirow{2}{*}{ Nilai Nyeri Disminore } & \multirow{2}{*}{ Mean } & \multirow{2}{*}{ SD } & \multirow{2}{*}{ SE } & \multicolumn{2}{c}{ CI (95\%) } & \multirow{2}{*}{ T } & \multirow{2}{*}{ N } & \multirow{2}{*}{ P value. } \\
\cline { 5 - 6 } & & & & Lower & Upper & & & \\
\hline Sebelum dan Sesudah Bekam & 1.688 & 0.931 & 0.165 & 1.352 & 2.023 & 10.252 & 32 & 0.000 \\
\hline
\end{tabular}

\section{Pembahasan}

\section{Rata-rata nilai nyeri disminore sebelum perlakuan bekam}

Nyeri haid (dismenore) merupakan gangguan fisik yang sangat menonjol pada wanita yang sedang mengalami menstruasi berupa gangguan nyeri atau kram pada perut (Lestari, 2011). Hasil penelitian ini memperlihatkan pengukuran skala nyeri pada responden sebelum diberikan perlakuan bekam sebagian besar berada pada skala nyeri berat $(56,25 \%)$ dan nyeri sedang berjumlah $43,75 \%$.

Fisiologi nyeri secara umum terjadi sesungguhnya karena adanya sesuatu yang salah telah terjadi dalam tubuh. Salah satu penyebab nyeri antara lain adalah ketidaklancaran sirkulasi darah, hal ini terjadi karena endapan asam laktat (lactic acid) akibat kelelahan otot atau pembentukan beberapa zat kimiawi karena kematian sebagian jaringan. Penyebab nyeri yang lain adalah karena kelebihan suhu, cedera kinetic atau cedera pembuluh darah terjadi karena sekresi beberapa enzim yang mengeluarkan beberapa zat penyebab nyeri seperti bradikinin dan histamine (Syaraf, 2012). 
Kejadian dismenore yang bukan patologis atau dismenore primer terjadi karena peningkatan prostaglandin ( $P G)$ F2-alfa yang merupakan suatu siklooksigenase (COX-2) yang mengakibatkan hipertonus dan vasokonstriksi pada miometrium sehingga terjadi iskemia dan nyeri pada bagian bawah perut. Adanya kontraksi yang kuat dan lama pada dinding rahim, hormon prostaglandin yang tinggi dan pelebaran dinding rahim saat mengeluarkan darah haid, sehingga terjadilah nyeri saat haid. Bentuk dismenore yang banyak dialami oleh remaja adalah kekakuan atau kejang di bagian bawah perut. Rasanya sangat tidak nyaman sehingga menyebabkan mudah marah, gampang tersinggung, mual, muntah, kenaikan berat badan, perut kembung, punggung terasa nyeri, sakit kepala, timbul jerawat, tegang, lesu, dan depresi. Gejala ini datang sehari sebelum haid dan berlangsung 2 hari sampai berakhirnya masa haid (Marlina, 2012).

Responden yang mengalami disminore dengan tingkat nyeri sedang merasakan ketidaknyamanan, bahkan sampai tidak mampu berkonsentrasi dalam mengikuti kegiatan belajar. Untuk responden yang mengalami nyeri berat tidak bisa mengikuti kegiatan pembelajaran belajar baik terori maupun praktik. Perlunya penanganan dismenore tidak hanya dengan terapi konvensional (medis), namun juga terapi komplementer, termasuk bekam.

\section{Efek tindakan bekam terhadap penurunan skala nyeri dismenore}

Penelitian memperoleh hasil terdapat efektifitas atau pengaruh bekam terhadap penurunan ratarata nilai nyeri dismenore pada responden. Efek terhadap nyeri setelah perlakuan bekam kasus dismenore terjadi penurunan skala nyeri rata-rata 1,69 dari skala 6,78 menjadi skala 5,09 (skala nyeri 0$10)$.

Hasil penelitian ini sesuai dengan hasil penelitian Umar tahun 2010 yang mengungkapkan bahwa teori kedokteran saat pembekaman pada titik bekam, maka akan terjadi kerusakan mast cell dan lain-lain pada kulit, jaringan bawah kulit (sub kutis), fascia dan ototnya. Akibat kerusakan ini akan dilepaskan beberapa mediator seperti serotonin, histamine, bradikinin, slow reacting substance (SRS), serta zat-zat lain yang belum diketahui. Zat-zat ini menyebabkan terjadinya dilatasi kapiler dan arteriol, serta flare reaction pada daerah yang dibekam. Dilatasi kapiler juga dapat terjadi di tempat yang jauh dari tempat pembekaman. Ini menyebabkan terjadinya perbaikan mikrosirkulasi pembuluh darah. Akibatnya timbul efek relaksasi (pelemasan) otot-otot yang kaku dan akibat vasodilatasi umum yang dapat menurunkan tekanan darah secara stabil. Selain itu, yang terpenting adalah dilepaskannya corticotrophin releasing factor (CRF) dan releasing factors lainnya oleh adenohipofise. CRF selanjutnya akan menyebabkan terbentuknya ACTH, corticotrophin dan corticosteroid. Corticosteroid ini mempunyai efek menyembuhkan peradangan serta menstabilkan permeabilitas sel (Umar, 2015)

.Penelitian lain menunjukkan bekam pada titik tertentu dapat menstimulasi kuat syaraf permukaan kulit yang akan dilanjutkan pada cornu posterior medulla spinalis melalui syaraf A-delta dan C, dan traktus spinothalamicus kearah thalamus yang menghasilkan hormon endorphin. Sedangkan, sebagian rangsang lainnya akan menimbulkan reflek intubasi nyeri. Hasil penelitian ini sesuai dengan penelitian yang dilakukan oleh Yanti tahun 2011 tentang pengaruh terapi bekam perubahan skala nyeri pada pasien dengan nyeri kepala di Klinik Afiat dengan hasil bahwa skala nyeri sebelum dibekam 4,5 \pm 1,265 turun menjadi $2,69 \pm 1,401$. Penurunan skala nyeri ini signifikan secara statistik bahwa terapi bekam berpengaruh terhadap perubahan skala nyeri ( $\mathrm{p}$ value 0,000$)$ (Yanti, 2011).

Hasil penelitian lain oleh Sharaf tahun 2012 yang menyatakan bahwa terapi bekam mengeluarkan sel darah yang tua dan rusak, disamping zat lain yang tidak dibutuhkan tubuh dan menyebabkan timbulnya penyakit, sehingga terwujudlah kesembuhan dengan izin Allah. Bekam merupakan salah satu metode pengobatan yang dicontohkan dan dianjurkan oleh Rasulullah Shalallahu 'alahi wasalam. Sesungguhnya penyakit yang diderita oleh seseorang, niscaya memiliki obat. Termasuk obat dan cara pengobatan yang Rasulullah ajarkan kepada ummat adalah hijamah (bekam), bahkan 
dikatakan sebagai sebaik-baik pengobatan. Bekam adalah metode terapi yang kini kembali muncul dan menjadi trend. Pelatihan bekam dan prakteknya menarik minat banyak dokter, setelah kajian-kajian ilmiah di berbagai negara di dunia membuktikan efektifitas metode terapi ini untuk mengobati dan memperingan berbagai keluhan penyakit, khususnya karena bekam memiliki kedudukan istimewa dalam tradisi pengobatan Nabi (Syaraf, 2012).

Bekam mampu menurunkan tingkat nyeri pada gangguan disminore. Riset bekam membuktikan bahwa bekam itu merupakan Sunnah Nabi yang ilmiah. Melihat mekanisme kerja bekam, ternyata bekam sangat bermanfaat bagi tubuh orang yang sedang mengalami gangguan peredaran darah dan rasa nyeri yang dialaminya, karena; 1) Bekam meningkatkan elastisitas dinding eritrosit melewati celah kapiler untuk menghantarkan $\mathrm{O} 2$; 2) Bekam meningkatkan antioksidan alami; glutathione peroksidase dan catalase. 3) Merangsang eritropoesis (produksi sel darah merah) di tulang/ginjal; 4) Meningkatkan jumlah makrofag; 5) Meningkatkan sel natural killer; 6) Meningkatkan limfosit T CD8+; dan 7) Menurunkan radikal bebas (Widada, 2010).

Hendaknya tenaga kesehatan, termasuk Bidan menjadikan bekam sebagai bagian terapi komplementer dalam asuhan pelayanan praktik mandiri untuk mengurangi masalah disminore, karena mempunyai kewenangan untuk mengatasi gangguan kesehatan reproduksi remaja atau wanita. Adapun Bidan yang mempunyai kewenangan melakukan tindakan bekam, jika telah lulus uji kompetensi terapis bekam setelah mengikuti pelatihan Bekam.

\section{Simpulan dan saran}

Bekam memberikan efek atau pengaruh menurunkan skala nyeri pada dismenore. Efek terhadap nyeri setelah perlakuan bekam kasus dismenore terjadi penurunan skala nyeri rata-rata 1,69 dari skala 6,78 menjadi skala 5,09 (skala nyeri 0-10). Bekam menjadi salah satu terapi komplementer atau upaya yang direkomendasikan untuk mengatasi gangguan rasa nyeri disminore dan bebas dari akibat atau komplikasi dari mengkonsumsi obat-obat kimiawi.

\section{Referensi}

Anurogo, D., \& Wulandari, A. (2012). Cara jitu mengatasi nyeri haid. Yogjakarta: C.V Andi Ofset.

Asri, R., Sinar, P., \& Siti, P. (2017). Pengaruh Endorphine Massage Terhadap Rasa Sakit Dismenore Pada Mahasiswi Jurusan Kebidanan Poltekkes Kemenkes Tasikmalaya Tahun 2017. Jurnal Bidan "Midwife Journal'. 3 (2)

Bidan \& Dosen Kebidanan. (2018). Kebidanan Teori dan Asuhan (Vol. 2). Jakarta: Buku Kedokteran EGC.

Bobak, L. J. (2012). Buku ajar keperawatan maternitas. Jakarta: Buku Kedokteran EGC.

Hacker \& Moore. (2015). Essentials of obstetrics and gynecology (6 ed.). Singapura: Elsevier.

Laila, N. N. (2011). Buku pintar menstruasi. Buku Biru: Jogjakarta.

Lestari, N. (2011). Tips praktis mengetahui masa subur. Yogyakarta: Katahati.

Marlina, E. (2012). Pengaruh minuman kunyit terhadap tingkat nyeri dismenore primer pada remaja putri di SMA Negeri 1 Tanjung Mutiara Kabupaten Agam. Disertasi. Padang: Universitas Andalas.

Ningsih et al. (2011). Hubungan Aktivitas Fisik (olahraga) Dengan Tingkat Nyeri Disminore.

Prabekti. (2012). Tips dan trik merawat organ intim. Jakarta: Sagung Seto.

Proverawati, A. S. (2009). Buku ajar gizi untuk kebidanan. Yogyakarta: Nuha Medika.

Purnamawati, A. (2012). Efektifitas pemberian Informasi kesehatan keproduksi terhadap penurunan perilaku merokok pada remaja putri. Journal of Consulting and Clinica Psychology, 7 (4).

Sari, W. (2012). Panduan Lengkap Kesehatan Wanita. Jakarta: Penebar Plus+ (Penebar Swadaya Grup). 
Efek Bekam terhadap Penurunan Nyeri Dismenoroe pada Mahasiswa

Yusro Hadi Maksum, Sri Lestariningsih, Septi Widiyanti

Jurnal Kesehatan Metro Sai Wawai. Volume 12 (1) Juni 2019. E-ISSN 2657-1390. P-ISSN 19779-469X

Savitri, R. (2015). Gambaran skala nyeri haid pada usia remaja. Skripsi Sarjana. Stikes 'Aisyiyah Cimahi, Bandung.

Syaraf, A. R. (2012). Penyakit dan terapi bekamnya: dasar-dasar ilmiah terapi bekam. Surakarta: Thibbia.

Widada, W. (2010). Riset bekam membuktikan sunnah Nabi yang ilmiah. Bandung: Lubuk Agung.

Umar, W. A. (2015). Yusuf (2015), Titik Bekam 40 Penyakit. Solo.: Thibbia.

Yanti, R.F., (2011). Pengaruh terapi bekam terhadap perubahan skala nyeri pada pasien dengan nyeri kepala di Klinik Afiat. Retrieved from http://repository.uinjkt.ac.id/dspace.

Yurisda, A. (2015). Pengaruh senam terhadap penurunan Intensitas Nyeri disminore pada Mahasiswa DIII Kebidanan Stikes Aisyiyah Yogyakarta. Skripsi Sarjana. Stikes 'Aisyiyah Yogyakarta, Retrieved http://digilib.unisayogya.ac.id/1866/1pdf, [7 Oktober 2018]. 